\title{
Security mechanisms for insolvencies in the package travel sector: an economic analysis
}

Citation for published version (APA):

Faure, M. G., \& Weber, F. (2013). Security mechanisms for insolvencies in the package travel sector: an economic analysis. Journal of Consumer Policy, 36(4), 425-442. https://doi.org/10.1007/s10603-0139222-4

Document status and date:

Published: 01/01/2013

DOI:

10.1007/s10603-013-9222-4

Document Version:

Publisher's PDF, also known as Version of record

Document license:

Taverne

Please check the document version of this publication:

- A submitted manuscript is the version of the article upon submission and before peer-review. There can be important differences between the submitted version and the official published version of record.

People interested in the research are advised to contact the author for the final version of the publication, or visit the DOI to the publisher's website.

- The final author version and the galley proof are versions of the publication after peer review.

- The final published version features the final layout of the paper including the volume, issue and page numbers.

Link to publication

\footnotetext{
General rights rights.

- You may freely distribute the URL identifying the publication in the public portal. please follow below link for the End User Agreement:

www.umlib.nl/taverne-license

Take down policy

If you believe that this document breaches copyright please contact us at:

repository@maastrichtuniversity.nl

providing details and we will investigate your claim.
}

Copyright and moral rights for the publications made accessible in the public portal are retained by the authors and/or other copyright owners and it is a condition of accessing publications that users recognise and abide by the legal requirements associated with these

- Users may download and print one copy of any publication from the public portal for the purpose of private study or research.

- You may not further distribute the material or use it for any profit-making activity or commercial gain

If the publication is distributed under the terms of Article $25 \mathrm{fa}$ of the Dutch Copyright Act, indicated by the "Taverne" license above, 


\title{
Security Mechanisms for Insolvencies in the Package Travel Sector: an Economic Analysis
}

\author{
Michael G. Faure • Franziska Weber
}

Received: 12 July 2012 / Accepted: 21 February 2013 /

Published online: 3 May 2013

(C) Springer Science+Business Media New York 2013

\begin{abstract}
Company insolvencies can lead to potential financial losses for consumers. Insolvency can clearly also create a severe problem for consumers who are disappointed because the travel that they were anticipating cannot take place or has to be interrupted. Insolvency may create a negative image for the entire travel sector as well; as a result, the sector itself has developed a variety of guarantee mechanisms. Moreover, governments in some legal systems have also intervened to guarantee compensation to consumers who are confronted with an insolvent travel company. The mechanisms in this respect are quite divergent. In addition, this phenomenon of providing security in the case of insolvency in the package travel sector has not yet been analysed from an economic perspective. Nevertheless, these mechanisms pose interesting questions from an economic viewpoint, inter alia with respect to the rationale for creating such a mechanism, but also related to the issue of whether either the sector itself or the government should organise a security mechanism. The goal of this paper is therefore to examine mechanisms geared to ensure financial compensation to consumers in instances of insolvencies in the package travel sector. A law and economics approach will be used to critically review these security mechanisms. In this ambit, the different mechanisms opted for in the UK, The Netherlands, and Sweden will be displayed and analysed.
\end{abstract}

Keywords Package travel · Security mechanism · Insolvency · Law and economics · Comparative law

\section{Introduction}

Company insolvencies can lead to potential financial losses for consumers. Insolvency can clearly also create a severe problem for consumers who are disappointed because the travel that they were

\footnotetext{
M. G. Faure

Faculty of Law, Metro, University of Maastricht, PO Box 616, Maastricht 6200 MD, The Netherlands e-mail: michael.faure@maastrichtuniversity.nl

M. G. Faure

Erasmus School of Law (Rotterdam Institute of Law and Economics), Erasmus University Rotterdam (EUR), 3000 DR Rotterdam, The Netherlands

F. Weber $(\bowtie)$

Erasmus School of Law (Rotterdam Institute of Private Law), Erasmus University Rotterdam (EUR), 3000 DR Rotterdam, The Netherlands

e-mail: f.weber@law.eur.nl
} 
anticipating cannot take place or has to be interrupted. Insolvency may create a negative image for the entire travel sector; as a result, the sector itself has developed a variety of guarantee mechanisms. Moreover, governments in some legal systems have also intervened to guarantee compensation to consumers who are confronted with an insolvent travel company. The mechanisms in this respect are quite divergent. In addition, this phenomenon of providing security in the case of insolvency in the package travel sector has not yet been analysed from an economic perspective (Halbhuber and Hondius 1996) ${ }^{1}$. Nevertheless, these mechanisms pose interesting questions from an economic viewpoint, inter alia with respect to the rationale for creating such a mechanism, but also related to the issue of whether either the sector itself or the government should organise a security mechanism. A crucial question also concerns how the security mechanism can provide to the companies involved in the travel sector (positive or negative) incentives to optionally invest in preventing insolvency.

The goal of this paper is therefore to mechanisms examine geared that ensure financial compensation to consumers instances of insolvencies in the package travel sector. A law and economics approach will be used to critically review these security mechanisms.

The paper starts by providing various rationales for promoting security mechanisms (deterrence, prevention, and compensation) in "Rationale for Security Mechanisms." We then turn to a comparison of two instruments that can typically be used to provide compensation to disappointed consumers: namely, being insurance and an insolvency fund. This will lead to the formulation of a few indicators for an adequate response in cases of insolvencies ("Insurance versus Insolvency Fund").

After this theoretical exercise, the package travel sector is looked at in detail. Article 7 of the European Union (EU) package travel directive sets out that "the organizer and/or retailer party to the contract shall provide sufficient evidence of security for the refund of money paid over and for the repatriation of the consumer in the event of insolvency" (Halbhuber and Hondius 1996). ${ }^{2}$ This shows that, within the EU, the directive forces Member States (MS) to put into place a system that guarantees compensation to the consumer in the event of insolvency. However, the directive does not indicate what this compensation mechanism should comprise. Article 7 would thus appear to leave the choice of mechanisms that ensure "sufficient evidence of security" to the MS. The different mechanisms opted for in the UK, The Netherlands and Sweden will consequently be displayed and discussed ("The Travel Sector").

After describing the different mechanisms used to compensate consumers in three MS, the economic framework as set out in "Insurance versus Insolvency Fund" will be used to provide a critical comparative economic analysis in "Analysis." "Concluding Remarks" concludes.

\section{Rationale for Security Mechanisms}

Various rationales for financial guarantees/security mechanisms in insolvency situations are imaginable. Departing from the acknowledgement that insolvency is often

\footnotetext{
${ }^{1}$ See, however, the interesting contribution by Halbhuber and Hondius; their main scope is the legal analysis of security mechanisms, but they briefly mention the economic perspective as well.

${ }^{2}$ Council Directive 90/314/EEC of 13 June 1990 on package travel, package holidays and package tours, OJ L $158,23 / 06 / 1990$, pp. 59-64. See the comprehensive list of early literature referred to in Halbhuber and Hondius 1996. A revision of the package travel directive is currently taking place: see http://ec.europa.eu/ consumers/rights/travel_en.htm\#travel and http://ec.europa.eu/justice/consumer-marketing/travel/package/ index_en.htm, as of 8 June 2012. See for the points of view of different stakeholders: http://ec.europa.eu/ consumers/rights/package_travel_responses_en.htm. The last stakeholder meeting was held on 5 June 2012, discussing issues such as the scope of dynamic packaging and its inclusion in a revised directive, liability regimes and the question as to whether MS laws should be approximated.
} 
caused at least in part by undesirable behaviour, and is thus the breach of legal duties of the trader, from an economic point of view, these situations can be looked at from a deterrence perspective. This approach stresses the need to internalise the costs of the harm caused by the trader by making him face a sanction that multiplied by the probability of detection and conviction at least equals his possible gain from a violation (Becker 1968). The reasoning behind this approach is to deter violations of the law by increasing costs for the individual, in this case, companies. Specifically for the travel sector, it may be important to prevent "bad guys" from running off in cases of insolvencies if they can be tied to a mechanism that ex ante secures their liquidity for times of insolvencies. In terms of fine tuning such a mechanism, prospects of being reimbursed if no insolvencies occur can be an interesting avenue to explore when it comes to steering traders' incentives.

In other words, insolvency is a problem from an economic perspective, since it would allow some traders to gain particular benefits from consumers and to engage in risky behaviour, exposing themselves to the danger of insolvency. In the absence of a security mechanism, the trader could hence externalise the costs of insolvency to the consumers, which, in turn, would lead to under-deterrence. The risk of under-deterrence resulting from insolvency has been stressed especially in economic literature with respect to torts. The judgment proof problem could create incentives to externalise harm to third parties, more particularly tort victims (Shavell 1986). However, under-deterrence can also arise in a contractual context such as in the case of a contract between a travel agent and a consumer. Of course, the question arises as to whether the market mechanism would be able to remedy this under-deterrence. This would certainly be the case if ex ante consumers were sufficiently aware of which travel agents posed an insolvency risk. This could lead consumers to either refrain from doing business with seemingly high risk operators or consumers would ex ante seek first party insurance coverage against the risk of losses resulting from insolvency. They would add these insurance costs to the-presumably-cheaper prices offered by risky travel operators, which would remedy the insolvency. This market mechanism, however, supposes that consumers are well informed about the potential insolvency risks posed by the different operators, and are able to weigh these risks and to act accordingly. To some extent, consumers may indeed be able to generally assess whether long-standing traditional travel agencies are more financially solid than smaller new travel agencies which may have less capital and thus pose a more serious insolvency risk. However, seemingly large and longstanding travel agencies can also become insolvent; a few bankruptcies involving larger travel agents as well have proven this point. ${ }^{3}$ These types of risks are not always foreseeable by consumers as a result of which information deficiencies may remain. The information deficiency concerning a travel agent's potential insolvency would then constitute the market failure, which in turn would justify introducing security mechanisms.

As a second goal, and in fact one that is often regarded as a complementary to deterrence, prevention-institutionalising the need to take precaution upfront to avoid a possible inability to perform or pay and compensate later on — can be mentioned.

\footnotetext{
${ }^{3}$ Forty-one travel companies went bankrupt in the UK in 2011, see http://www.wilkinskennedy.com/ news-and-press/press-releases/41-tour-operators-and-travel-agents-go-bankrupt-in-the-last-year, as of 8 June 2012; "Rainbow tours" went bankrupt in 2012: http://www.abendblatt.de/hamburg/article2161434/ Reiseveranstalter-Rainbow-Tours-wird-abgewickelt.html, as of 8 June 2012. See also Meglena Kuneva's (then European Consumer Commissioner) speech concerning the "Revision of the Package Travel Directive" and the bankrupties cited these, http://ec.europa.eu/consumers/rights/docs/speech_travel_ package_en.pdf, as of 8 June 2012.
} 
As a third goal, victim compensation can be discussed. From an economic perspective, the mere fact that victims would not be compensated as a result of insolvency is not necessarily a problem unless such insolvency were to create a market failure. Since an information deficiency may create under-deterrence, there can indeed be a market failure, depending upon the empirical proof concerning the existence of such an information deficiency. For lawyers, especially those active in the field of consumer law, victim compensation could also be considered a separate policy goal (Micklitz 2004, p. 345). ${ }^{4}$ However, if victim compensation were to be considered a policy goal, crucial questions would still emerge, related, for example, to the scope of the compensation and to the question of who would have to provide the compensation in general in an insolvency situation.

\section{Insurance versus Insolvency Fund}

Core Indicators

\section{Ability to Enforce Risk Differentiation}

Combining the reasoning of the various rationales (deterrence, prevention, and compensation), the following core criteria for the design of a financial guarantee stand out. A first aspect is that no matter how a compensation system is organised it must always include incentives for proper behaviour and more particularly incentives to prevent insolvency (Faure and Hartlief 1986). ${ }^{5}$ In economic terms, the problem that arises is the well-known one of moral hazard ${ }^{6}$ (Shavell 1979). The classic remedy for moral hazard is to let the risk creator contribute to a compensation solution to the extent to which he contributed to the risk. This is reflected in the idea of risk differentiation. In insurance policies, this simply means that a higher premium is paid for bad risks than for good ones (Priest 1987). ${ }^{7}$ This principle should also be applied if a compensation fund is established, meaning that bad risks should contribute more to the compensation system than good risks. This is an important aspect since it provides the contributors with incentives for prevention. Thus, financing of the compensation mechanism is essential since bad risks will be punished and good risks will be rewarded.

These principles are not only important from an efficiency point of view (providing optimal incentives for prevention); they also include a fairness element. Indeed, if they were not followed, it would mean that the good risks would have to pay for the bad ones and would therefore be effectively subsidising them. Such a negative redistribution should be avoided, therefore, the compensation mechanism, whether fund or insurance, ought to be financed principally by those who contributed substantially to the risk. Accordingly, the compensation mechanism should aim to differentiate between the contributions due.

\section{Scope of the Compensation Mechanism}

A next question concerns the scope of the various compensation mechanisms. After all, there should not necessarily be a choice between either insurance or a fund.

\footnotetext{
${ }^{4}$ On some principles of consumer protection.

${ }^{5}$ See for an application with respect to environmental damage.

${ }^{6}$ Moral hazard is the well-known phenomenon that the behaviour of the insured will change as soon as the risk is removed from him/her. Hence, insurance can contribute to a change in the behaviour of the insured which in fact increases the risk. That precisely is moral hazard (Faure and Hartlief 2003, p. 107).

${ }^{7}$ The importance of risk differentiation in insurance has often been stressed, inter alia by Priest.
} 
Theoretically, a coordination could take place whereby, for example, the compensation would first be due from the insurer of the travel agent and the compensation fund would only intervene to the extent that the insurer becomes insolvent. In that case, the compensation fund would not fully replace insurance but would be a guarantee fund, intervening only in the case of the insurer's insolvency. Such a combined use of the liability and insurance system with a guarantee fund has the advantage that the incentives of the liability system remain, and the fund will only need to intervene in the event of the insurer's insolvency.

\section{Voluntary or Compulsory?}

Finally, the question remains as to whether the system needs to be made compulsory. This would, of course, require a governmental intervention. As mentioned above, insolvency has, in the economic literature, often been advanced as a reason for introducing compulsory insurance (Faure 2006). The argument is that insolvency may create a problem of under-deterrence, that could be solved by compulsory insurance (Jost 1996). When a potential injurer is under a duty to insure, the insurer will have incentives to control the behaviour of the potential injurer via the control of moral hazard. Hence, provided that the moral hazard problem can be adequately remedied, compulsory insurance can yield better results than the judgment proof scenario. In other words, if there were empirical evidence that a serious market failure would arise (resulting from information deficiencies), there would also be a reason to make a compensation mechanism (either fund or insurance) mandatory. In the absence of a mandatory system, the danger might emerge that it would more particularly be the "bad guys" who would not seek insurance coverage and who therefore continue to externalise their insolvency risk to consumers.

The question will now be addressed as to whether these key features of a compensation mechanism can be tackled better via insurance or via a fund.

\section{Insurance or Funds?}

The crucial question arises as to which mechanism is best able to remedy the insolvency problem taking into account the previously mentioned principles. In principle, a wide variety of mechanisms could be used to resolve insolvency situations (Faure 2004). In addition to the insurances and insolvency funds that will be focused on in this contribution, one might also consider ex ante guarantees, deposit mechanisms, or risk pooling by operators. ${ }^{8}$ Even though these alternative mechanisms are certainly (at least theoretically) important as well, for a variety of reasons they do not play a large role in practice; for this reason, the focus will turn to a comparison between insurance and funds. ${ }^{9}$

\footnotetext{
${ }^{8}$ A financial guarantee could, e.g., be provided by a third party such as a financial institution; a deposit mechanism would imply an obligation of the operator to deposit funds in a separate account that could be used in the event of insolvency. Risk pooling is a risk sharing between various operators that would mutually share each other's losses on an ex ante basis. For a discussion of these schemes see Faure and Hartlief (2003, pp. $162-165$ and $168-169)$.

${ }^{9}$ Theoretically it is possible, for example to require from every package travel operator a deposit to cover his potential future liabilities. However, the costs of such a deposit (which may require the immobilisation of substantial capital for a longer time) are of course substantial, as a result of which this mechanism is less used in practice.
} 


\section{Ability to Enforce Risk Differentiation}

Looking at the first criterion, that being whether it is possible to organise a compensation mechanism in such a way that a differentiation takes place between the contributions due, insurance clearly has the advantage that it is able to differentiate risks and in that way the traditional moral hazard problem can be tackled. The manner in which insurance traditionally operates is that the insurance company monitors the behaviour of the insured operators and adapts the premium accordingly. Insurers will, also by specialising on particular risks, be able to differentiate between good and bad risks, and adapt premiums accordingly. Moreover, insurers guaranteeing the solvency of travel operators will not only monitor their insured members adequately but will impose particular conditions and restrictions as a result of which the risk is reduced.

If insurance is not used, but a fund is to guarantee the solvency of the travel operators, the question arises as to whether the fund is able to apply the differentiation in the same way as an insurance company would. A first problem that arises is that it may be difficult for the administrator of a fund to have access to information allowing a differentiation of the risks. After all, risk differentiation supposes that the insurer knows what the good and bad risks are. If the fund were operated by an administrator specialised in the travel sector, it would be possible to ask for risk-dependent contributions that could provide travel operators with incentives for prevention. This advantage of course disappears if operators merely have to contribute to the fund via a lump sum (hence without any risk distribution). In that case, the fund would become particularly attractive for bad risk operators that could thus free ride on the good risks and the above-mentioned danger of negative redistribution would emerge.

The question of whether the fund is able to differentiate risks will, in practice, be strongly related to whether the fund is government operated or operated by the sector itself. A government agency may not necessarily have adequate information to differentiate the risks and will, in practice, often ask for a lump sum contribution as a result of which moral hazard, free riding, and a negative redistribution may arise. If the fund were, however, run by operators, it would function as a risk sharing agreement. This would have the advantage that operators would have a strong incentive for mutual monitoring and also have adequate information regarding the risks (Coghlin 1994). ${ }^{10}$ From the operators' perspective, the risk-sharing agreement would also have the advantage that no premiums (to an insurer) or contributions to a government fund would have to be paid. Hence, if no accident happened, the money paid to the fund operated by the operators would not be lost and could in principle be paid back and redistributed among the members.

In summary, if a fund is not considered to be government operated, but rather a risk-sharing agreement between operators, it may present an interesting alternative to insurance. The question then simply arises as to which of the two mechanisms is better able to control risks and charge risk-dependent premiums. If insurance companies are specialised and can obtain adequate information, insurance may work. If, however, information is hard to obtain for commercial insurance companies, a fund operated by operators may have the advantage that they can carry out in mutual monitoring of risks and thus control moral hazard. In the situation whereby operators are better able than the insurer to process information on particular risks, an operator-run fund (better designated as a risk sharing agreement) may be preferred.

\footnotetext{
${ }^{10}$ Risk-sharing agreements are used for example in highly specialised matters such as the coverage of marine oil pollution. This risk is covered via protection and indemnity clubs, which are a mutual risk-sharing agreement between tanker owners.
} 


\section{Scope of the Compensation Mechanism}

As to the second criterion, an interdependency can exist between insurances and funds when, for instance, setting up a fund on the basis of having an insurance system in place. The fund would then only step in, to cover situations in which insurance fails, when parts are not covered by it or in insolvency situations involving insurance companies. The advantage of such a mechanism would be that the fund (in this hypothesis government run) would function more as a guarantee fund, that would only intervene to protect victims against the possible insolvency of the insurer. In this case, insolvency would be covered principally by the liable travel operator and his insurer (or via a risk-sharing agreement that fulfills the role of a mutual insurance). In this case, a fund (even if government run) would intervene as a mechanism of last resort, after other mechanisms had first been applied (Faure and Heine 2012). ${ }^{11}$

\section{Voluntary or Compulsory?}

As to the third criterion, concerning whether the mechanism should be mandatory, as indicated above, there are strong arguments to say it should. To the extent that there is indeed proof of an information deficiency resulting in a market failure, there may be strong arguments that support making the system (either insurance or a fund) compulsory. In the absence of a compulsory system, free riding by "catch me if you can" traders would still arise and the under-deterrence problem would not be solved.

Following this theoretical exposé, let us now, examine which security mechanisms dealing with insolvencies in the travel package sector exist in a few MS.

\section{The Travel Sector}

\section{The EU Directive}

The package travel directive is regarded as a sign that the EU during that time absorbed an increasing impact in transport law. It deals with cases of "package travels," a term that, according to Art. 2 (1)(c) of the directive, refers to a pre-arranged combination of no less than two elements - either transport and accommodation or transport and other tourist services, not ancillary to transport or accommodation. The main goal of the directive is consumer protection (Halbhuber and Hondius 1996, p. 318). It sets out a strong policy of liability and thus considerably strengthens consumer protection. It sets out the obligation for the travel sector to provide for guarantees in insolvency situations. Article 7 of the package travel directive reads "the organizer and/or retailer party to the contract shall provide sufficient evidence of security for the refund of money paid over and for the repatriation of the consumer in the event of insolvency." Article 7 would thus appear to leave the choice of mechanisms that ensure "sufficient evidence of security" to the Member States; and in the following, the different solutions this has led to for the UK, The Netherlands, and Sweden will be examined. ${ }^{12}$ Article 7 establishes a minimum level of protection that the organiser/retailer should provide when referring to the range of the protection, namely, the "refund of money paid over or repatriation of the consumers" (Halbhuber and Hondius 1996, p. 309). The directive uses the term "refund" only with respect to cancellation of the

\footnotetext{
${ }^{11}$ Such a mechanism has also been proposed to deal with risks resulting from the financial crisis.

${ }^{12}$ An overview of different available mechanisms in the various MS is given in Schulte-Nölke 2007, p. 320. We will carry out an even more thorough investigation in the chosen three MS.
} 
package travel before the agreed date of departure. Prepayments are to be refunded only before the trip has started. The meaning of the terms "sufficient evidence of security" has been assessed in the ECJ's case law. In the case Dillenkofer (ECJ judgment of 8 October 1996, C-178/94), the ECJ argued that any regulation allowing the tour organizer to require an uncovered deposit payment would contradict the purpose of Art. 7. A third party independent of the organizer and maintaining sufficient funds, is to be appointed as guarantor. The ECJ case Verein für Konsumenteninformation (ECJ judgment of 5 May 1998, C-354/96) specified further that all risks possibly arising from the insolvency of the tour organizer shall be fully covered. ${ }^{13}$ According to a recent case (C-134/11) decided by the Court of Justice of the European Union on 16 February 2012, "Article 7 of Council Directive 90/314/EEC of 13 June 1990 on package travel, package holidays and package tours is to be interpreted as covering a situation in which the insolvency of the travel organizer is attributable to its own fraudulent conduct."

As stated in the introduction the goal of this article is, to provide an economic analysis of the possible security mechanisms and then analyse more specifically the security mechanisms available in a few MS. Therefore we do not provide for a detailed analysis of other aspects of the travel package directive ${ }^{14}$ nor do we look at more EU MS since this would be beyond the scope of this article.

\section{Sweden}

In Sweden, the provisions on package travel are set out in the Travel Guarantees Act. ${ }^{15}$ It is set out that every operator is required to lodge an individual security with Kammarkollegiet (Legal, Financial and Administrative Services Agency) - a special state-financed agency. ${ }^{16}$ The operators arrange with a bank, insurance company, or credit market company for the security. The guarantee is then to be kept with Kammarkollegiet. ${ }^{17}$ The amount to be secured by each trader is determined individually, based on the company's own report regarding its business activities. ${ }^{18}$ Every operator must declare such activities according to the forms that can be found on the website. Most operators declare once a year, but some do so more often. If it is not the first time that the operator applies, the follow-up form must also be submitted stating the actual results of the last season. ${ }^{19}$ Failure to provide correct numbers can lead to monetary fines or prosecution. ${ }^{20}$ To calculate the amount that has to be paid the following factors are considered: number of passengers per month, cost of the travel arrangements; advance payments and cancellation fees, and how long before departure the payment must be made and repatriation costs. The sum is increased by $10 \%$ and then rounded off. All traders must have a valid security that covers at least 6 months out of a year. It is also possible if

\footnotetext{
${ }^{13}$ Additional ECJ cases concerning the interpretation of art. 7 are ECJ judgment of 15 June 1999 , C-140/97-Rechberger, ECJ judgment of 1 December 1998, C-410/96-Ambry.

${ }^{14}$ For a more detailed discussion, see inter alia Grant and Mason (2012).

${ }^{15}$ See email contact with Kammarkollegiet.

$16 \mathrm{http}: / / w w w . k a m m a r k o l l e g i e t . s e / e n g l i s h$.

${ }_{17}$ See email Kammarkollegiet, 13 January 2011. They keep about 2,000 guarantees at present.

18 See email Kammarkollegiet, 13 January 2011. See Art. 2 Travel Guaranties Act.

${ }^{19} \mathrm{http}: / / w w w . k a m m a r k o l l e g i e t . s e / e n g l i s h /$ travel-guarantees.

${ }^{20}$ See Art. 4a, 5, 14 Travel Guarantees Act: “Anyone who intentionally sells or markets travel without having lodged security as laid down in this act shall be sentenced to a fine or imprisonment for not more than one year. A fine shall be imposed on anyone who intentionally or through negligence

1. provides erroneous information when supplying particulars required in accordance with section 5 , or

2. fails to supply such particulars.[...]."
} 
profits are only made during a certain time of the year to lodge low security during most of the year and to complement this with high security during busy times. Consumers have to apply to the Travel Guarantees Board in the event of losses due to an operator's insolvency. A separate governmental board exists for these specific cases. ${ }^{21}$ The consumer must apply no later than 3 months after his return. ${ }^{22}$ In cases of a decision to compensate, Kammarkollegiet notifies the guarantee issuers that they will have to compensate the consumers ("on demand guarantee"). As stated, to ensure adherence and obedience to the system, e.g. for instances in which companies provide wrong numbers, companies can be fined. Furtheremore the Swedish Consumer Ombudsman (CO) as the defender of consumer rights can take action at the special Market Court to prevent market participation without lodging the securities required by Kammarkollegiet. In such a case, the Kammarkollegiet civil servants send their files to the $\mathrm{CO}$ and provide them with any extra information. Otherwise, the case is handled independently by that institution. ${ }^{23}$ Note for instance that in a case against Prima Travel AB, the company was forbidden to market tours without the necessary securities under a conditional financial penalty of 750,000 SEK. ${ }^{24}$ A similar issue was at stake in a case called Casa Nordica Altavista C AB from 2009 where due to the company's bankruptcy the case had to be dismissed in the Stockholm District Court. ${ }^{25}$ Involvement of the police is potentially possible. Criminal law plays a limited role in consumer protection, ${ }^{26}$ and is available for cases in which a trader violates the obligation to provide for financial securities in insolvency situations. Traders are occasionally reported by Kammarkollegiet. The trade association likewise indicate that if they find out about such a company, they report it to $\mathrm{CO}$ and/or Kammarkollegiet or even to the police. $^{27}$

As to the scope of the remedy, compensation is granted for the refund of money paid over and for the repatriation of the consumer in the event of insolvency as provided in Art. 7 of the Package Travel Directive. There is no other fund available, for instance for catastrophe situations, situations of force majeure. ${ }^{28}$ In exceptional circumstances, such as the tsunami in 2004, the government might still step in - when the tsunami occurred, the government and many travel companies took action to bring the travellers home.

\section{UK}

In the UK, provisions are set out in the Package Travel, Package Holiday, and Package Tours Regulations (PTRs). As possible security mechanisms, the Act mentions bond, insurance, and

\footnotetext{
${ }^{21}$ See Art. 9 Travel Guarantees Act. According to Art. 10, "This board consists of a chairperson and four other members, two nominees who can be considered to represent the interests of consumers and two who represent commercial interests. Each member shall have an adequate number of deputies. The chairperson and deputy chairperson are to hold or have held the office of judge.' The chairperson, other members of the board and their deputies are to be appointed by the government." Enactment (1988, p. 208).

22 Art. 8 Travel Guarantees Act.

23 See email Kammarkollegiet, 13 January 2011.

24 See email Kammarkollegiet, 10 October 2011, DOM 2008:6. 2008-04-11 Dnr B 2/07.

25 See email Kammarkollegiet, 10 October 2011. DOM 2009:17. 2009-06-26 Dnr B 9/08.

${ }^{26}$ See, for instance, personal email communications Prof. Antonina Bakardjieva-Engelbrekt, Professor of European Law, University of Stockholm (1 March 2012).

27 See personal email communications with Olsson, T.G., SRF (13 September 2011).

${ }^{28}$ See personal email communications with Kammarkollegiet (9 November 2012).
} 
trusts. The first option is a bond that is entered into by an authorized institution (Reg. 17). It has to amount to $25 \%$ of the annual turnover or the maximum amount of all payments the operator expects to hold at any time - whichever sum is smaller. Note that if the authorized institution has a reserve fund or insurance cover, the minimum amount of the bond falls to $10 \%$ of the organiser's/retailer's annual turnover (Reg. 18). Alternatively, as a second option, travel agents can take out insurance (Reg. 19). As a third option, all money paid over by a consumer for a package travel deal has to be held by a trustee for the consumer until the contract has been fully performed (Regs. 20 and 21). The local regulators, Trading Standards Services (TSS), are empowered with the supervision and enforcement of these provisions. Interestingly, the Association of British Travel Agents (ABTA) whose membership requirements entail the obligation to comply with the guarantee provisions for its members does not allow for the possibility to provide for trusts as they regard them as only providing for insufficient security. ${ }^{29}$ ABTA thus allows only for two out of three possible legal options. Overall, $90 \%$ of the package deals sold in the UK are offered by ABTA members, which leaves a low number of members that could possibly make use of the trusteeship system. The ABTA has an internal disciplinary mechanism for breaches of its code of conduct, of which providing the security is a part. Enforcement of the package holiday law is the responsibility of the TSS. ${ }^{30}$ The TSS are required to ensure that package holiday operators at all times provide sufficient evidence of security for the consumers' money and for the repatriation of the consumers should the package holiday operator collapse. As regards the requirement to provide for securities for possible insolvency situations, contraventions are stipulated to be offences and persons committing them are liable (a) on summary conviction to a fine not exceeding level 5 on the standard scale and (b) on conviction on indictment, to a fine. ${ }^{31}$ The same liability is incurred in cases of contraventions of the requirements of brochures (Reg. 5), information to be provided before contract is concluded (Reg. 7), information to be provided in good time (Reg. 8), and, or in particular breaches related to trusts (as set out in Reg. 22). Criminal prosecution is an important part of TSS enforcement. ${ }^{32}$ In their formal enforcement role, officers are required to operate to the same rules and standards as police officers and have to comply with the provisions of the Police \& Criminal Evidence Act 1984, the Criminal Procedure \& Investigations Act 1996, and with the Regulation of Investigatory Powers Act 2000. According to the explanatory schedule to regulation 23 in the PTRs, when carrying out a prosecution enforcement authorities in the UK have various powers regarding the production of books, documents, taking copies, and entry (with a warrant) or inspection of any good. People obstructing officers can be guilty of an offence. TSS in fact engage in prosecutions in relation to the "holiday sector" leading to fines and/or compensation. ${ }^{33}$ The cases' subject matter cannot be extracted from the annual reports of the Office of Fair Trading (OFT) which summarises TSS' action in the field of travel.

The TSS undertake their own prosecutions but will link with the police if the investigation reveals serious fraud issues such as Tour Operators not protecting consumers' money, collapsing the company, and disappearing. ${ }^{34}$

\footnotetext{
${ }^{29}$ See interview ABTA (London 22 February 2011).

30 See Regulation 23 (Schedule 3 enforcement) PTRs: 1.-(1) Every local weights and measures authority in Great Britain shall be an enforcement authority for the purposes of regulations 5, 7, 8, 16 and 22 of these Regulations ('the relevant regulations'), and it shall be the duty of each such authority to enforce those provisions within their area.

${ }^{31}$ See Regulation 16 (3) PTRs.

32 Cf. European Commission's working paper on Enforcement of European Consumer Legislation, 27 March 1998, SEC (98) 527, pp. 40.

${ }^{33}$ See as examples of the activity of TSS the respective annexes to the annual reports of the OFT that reflect TSS' action.

${ }^{34}$ See personal email communications TSS (21 February 2012).
} 
Criminal prosecutions can be brought either to the Magistrates Courts or to the Crown Court for the more serious cases (Faure et al. 2008, p. 388). ${ }^{35}$ In the Magistrates Courts, the prosecution is undertaken by the regulator itself, the case is tried summarily, and a maximum fine can be imposed. A case brought to the Crown Court must involve the Crown Prosecution Service, which decides whether it is appropriate for the prosecution to proceed. Fines and imprisonment are possible penalties for breaches of consumer protection law in the Crown Court. The trial is by indictment, and the fine is considerably higher than in the Magistrates Court.

Criminal law enforcement can happen via action that a public regulator takes or independently of a public regulator's action. According to English criminal law, the court can both fine a business and award compensation orders to consumers. In relation to damage payments in the criminal court, courts in the UK have a general power to order a person convicted of an offence to pay compensation for loss or damage resulting from that offence and for any personal injury, or for any other offence that is taken into consideration by the court in determining the sentence (Hodges 2009, p. 157). ${ }^{36}$ Note that if the claimant on top of the compensation order also claims damages in civil proceedings, the latter will be assessed without regard to the compensation order, but the claimant may only recover an amount equal to the aggregate of any amount by which the award of damages exceeds the compensation order or a sum equal to any portion of the compensation that he fails to recover. While conpensation orders are generally not often used, they have recently received more attention.

As regards monitoring security mechanisms, TSS regard it as their role to ensure compliance proactively by visiting all tour operators in the UK and to discuss any breaches notified by consumers. ${ }^{37}$ This proactive enforcement ensures that regulating the industry does not rely on penalising minor breaches of the legislation.

There are over $200 \mathrm{TSS}$ around the UK, and each has different priorities, governed by the councils who employ them. Thus approaches can vary, which is presumably the reason ABTA reported that the involvement of TSS is not so frequent overall. ${ }^{38}$ ABTA does refer non-members to the OFT/TSS when it comes to providing financial securities. In contrast to the situation in Sweden and in The Netherlands (to be discussed in the next paragraph), the national enforcer - the OFT plays no role in practice. ${ }^{39}$ When it comes to a possible OFT involvement, ABTA does not see a role for them in fining ABTA members. ${ }^{40}$ ABTA acknowledges that there is scope for abuse by traders and in the past, there have indeed been problems with malafide traders and cases of fraud have occurred. ${ }^{41}$ This has been tackled by involving the police, for instance to check traders' identities. ABTA regularly also checks websites of non-members.

Note that the situation changes as soon as flights are part of the package deal. ${ }^{42}$ Here, a different compensation system is in place - the Air Travel Trust (ATT). The Civil Aviation Authority (CAA) administers the Air Travel Organisers' Licensing (ATOL) Scheme, which provides financial protection to those taking flight-based holidays. Each consumer contributes

\footnotetext{
$\overline{35}$ Their paper is based on interviews with enforcers in 2006.

${ }^{36}$ Powers of Criminal Courts (Sentencing) Act 2000, ss. 130, 134.

37 See personal email communications TSS (21 February 2012). The interview partner calls the monitoring approach robust.

38 See interview ABTA (London 22 February 2011).

39 See ibid.

40 See ibid.

41 See ibid.

${ }^{4}$ See ibid.
} 
to the security mechanism with about $£ 2.50$ per flight. As soon as a flight is part of a package deal, the compensation works via this mechanism and the other securities remain untouched for the whole package. This system is currently running at a huge deficit.

As to the scope, there is no difference regarding Sweden. The same type of damage is covered.

\section{The Netherlands}

The obligation to provide for securities in cases of bankruptcies is set out in the Dutch Civil Code. ${ }^{43}$ Importantly, in The Netherlands, there is a fund available: Stichting Garantiefonds Reisgelden (SGR). This fund was established in 1983, and, up until 1 April 1999, consumers contributed to this fund each time they booked with an SGR participant. For many years this contribution was NLG 10 (about $€ 4.50$ ) and later NLG 15 (about $€ 6.80$ ). ${ }^{44}$ Since 1 April 1999 , the SGR guarantee is free for consumers, and compensation is paid purely from capital gain on the assets. The reason for this change is that, from a fiscal point of view, the fund was regarded as insurance, and taxes were to be paid.

If the consumer cannot go on holiday in the first place, he is compensated for that, and if the journey has to be interrupted, the fund also covers repatriation costs and other losses. Most of the travel operators are via trade association of travel companies-Algemene Nederlandse Vereniging van Reisondernemingen (ANVR) or independently of the ANVR participating in the SGR. The SGR fund covers approximately $95 \%$ of all advanced paid travel sums. About $5 \%$ of the operations in the travel sector are thus not secured through the fund. ${ }^{45}$ This $5 \%$ refers to the total turnover of the sector. Considering the high amounts of turnover in the package travel sector, $5 \%$ of uncovered travel is to be considered a relatively large amount. Furthermore it might be these operators in particular that get insolvent.

In addition, traders that are not ANVR members or are not registered independently with the SGR have to provide for an equivalent security. ${ }^{46}$ In order to become an SGR participant, a minimum capital requirement of $€ 18,000$ applies. This may exclude very small operators from the scope of application.

A company that ends up formally insolvent and thus faces problems in paying has to signal this to the SGR in which case the SGR might check this with the Chamber of Commerce. The SGR will disseminate this information to the sector. ${ }^{47}$ Usually the insolvent company will then provide an overview of the bookings that need to be compensated. While consumers are often greatful, some feel unfairly treated. There is no internal appeal procedure for consumers. There are, however, cases before the civil court and even in the criminal court that involve claims by consumers that feel unfairly treated by the SGR. ${ }^{48}$

In terms of scope, it is interesting that the SGR fund is designed primarily for the situations mentioned above. The fund is also available in cases of insolvency if the consumer has already

\footnotetext{
$\overline{43}$ Since 1991 this is made explicit in articel 7:512 Dutch Civil Code.

${ }^{44}$ Calculated here: http://nl.coinmill.com/EUR_NLG.html\#NLG=15.

${ }^{45}$ See email contact with SGR (24 January 20 11) and interview, Rotterdam (17 August 2011). Note: these companies can according to the rules of the ANVR also not become an ANVR member. From statistics of the CBS one can deduce this, the total amount of advance travel payments is 4.5 bn euro.

${ }^{46}$ To date there is no real alternative in the insurance market. Some companies via a notary store the money in a third bank account. The small travel operators are currently discussing introducing an own security scheme because participation in the SGR is very burdensome to them (e.g., as to the requirement to provide accounts). They have also sought advice of the Consumer Authority on this. Alternatives furthermore could be participation in foreign insolvency funds or cooperation with travel operators that are participants of the SGR. ${ }^{47}$ See interview with SGR, Rotterdam (17 August 2011).

${ }^{48}$ See ibid.
} 
acquired a "binding advice" from the Geschillencommissie Reizen $(G C) .{ }^{49}$ This works in the following way. Most package travel deals in The Netherlands are concluded with companies that adhere to the standard contract terms of the travel sector. These terms include a provision according to which the adjudication of possible breaches of the travel laws is to be done primarily by a centralised out of court dispute resolution body (the Geschillencommissie). This body is divided into about 50 boards for all types of consumer disputes. With the "binding advice" granted, the consumer can file a written application with the SGR. If, however, the procedure before the $G C$ is still ongoing, and the "binding advice" has not yet been issued when the compony gets insolvent- the consumer cannot turn to the SGR ${ }^{50}$ It has been suggested that, in the case of insolvency, the ADR committee may at times use its discretion to render a decision anyway. The extent to which this actually happens is unclear.

If the company turns out to be bankrupt before a consumer starts a procedure before the GC, he can turn to the civil court for compensation in situations not covered by the fund. ${ }^{51}$ Where the trader is not a fund participant in the first place, the ordinary insolvency procedure starts. ${ }^{52}$

Note again regarding non-participants: Anyone that is not an SGR participant cannot become an ANVR member in accordance with the rules of this sector organization. ${ }^{53}$ Operators that have their seat outside The Netherlands are obliged to comply with the insolvency regulations in their country.

What if a trader that is an SGR participant "disappears"? In these cases, the SGR will unilaterally declare insolvency, end the trader's participation in the SGR and compensate consumers in all cases of bookings that were made during the time of the respective trader's SGR participation. In cases of insolvency, if SGR participation is lost, ANVR membership is generally lost as well. ${ }^{54}$ SGR has the possibility to fine participants if they do not provide annual reports between $€ 250$, and $€ 10,000 .{ }^{55}$ The ultimate threat is termination of participation; ${ }^{56}$ hence this is a strong safety net. However, it does not apply to traders not participating in the fund in the first place.

The Consumer Authority (CA) - a public authority with fining powers same as private law enforcement powers - is active in checking whether traders provide for the required securities (on various occasions companies have been taken to court). The CA has scrutinised and will scrutinise in particular the companies that do not participate in the

\footnotetext{
${ }^{49}$ Email contact with, SGR (24 January 2011) the same is true with a court judgment.

${ }^{50}$ See interview with SGR, Rotterdam (17 August 2011): These cases in which a consumer turns to the SGR with a binding advice are rare and do constitute a substantial financial factor.

${ }^{51}$ See interview with Prof. T. Jongbloed, Professor of the Law of Enforcement and Seizure, Utrecht (26 January 2011).

52 The curator, appointed by the court, administers the bankruptcy situation and has to be contacted by the consumer. See http://www.consuwijzer.nl/Ik_wil_advies_over/Vakantie_en_vrijetijdsbesteding/Algemene informatie_over_reizen/Veelgestelde_vragen/Mijn_reisorganisator_is_failliet_en_niet_aangesloten_bij_de_SGR_Wat_kan_ik_doen.

${ }^{53}$ See interview with SGR, Rotterdam (17 August 2011 and 3 November 2011): There can be exceptions in particular for foreign traders that are members of ANVR but are excepted from being a member of the SGR because they fulfill the security requirements abroad.

${ }^{54}$ Interview ANVR, The Hague (13 April 2011).

55 See interview with SGR, Rotterdam (17 August 2011).

${ }^{56}$ See interview with SGR, Rotterdam (3 November 2011): termination of membership entails the possibility of losing clients: Those who cancel their participation themselves often want to get back into the fund; where the participation is cancelled through the SGR, this is much less the case. Lastly companies that went insolvent generally disappear from the market as such.
} 
SGR and it asks them to set out how they have organised their securities. As an example, the Gold Travel case can be mentioned (Loos and van Boom, 2010, p. 141). ${ }^{57}$ The CA won this case (28 April 2009), and the court declared that the trader was not fulfilling his obligation to provide securities for cases of insolvency. In relation to package travel, the CA can only make use of its civil law enforcement powers and has done this in about 10-11 cases, all of which it won. ${ }^{58}$ At the CA, they regard the Dutch Association of Travel Agents and Tour Operators as a very well working trade association which reports about non-members that do not provide for this guarantee.

There can be a role for criminal law if fraud comes into play. ${ }^{59}$ A consumer might consider himself to be dealing with a bona fide trader who in fact is only connected to the SGR on paper. SGR refers these cases to the public prosecutor.

In terms of competing funds, there is a catastrophe fund "Calamiteitenfonds" for as the name suggests cases of catastrophes. The consumers' contribution amounts to $€ 2.50$ for each booking. The administration is carried out by the SGR structure and is thus financed using part of the contributions made by traders.

\section{Analysis}

Taking into account the economic principles sketched previously, what can be said now regarding security mechanisms in Sweden, the UK, and The Netherlands?

To start with, due to the obligation set out in the European Directive that MS are bound to implement, providing for security mechanisms is of a mandatory nature in all the European MS. In the theoretical section this was indeed considered desirable. Rather than questioning the mandatory or voluntary nature of the mechanisms, the monitoring of the compliance with the obligation and the enforcement mechanisms shall be assessed here. ${ }^{60}$

The Swedish Kammarkollegiet allows various forms of guarantees, including a bank guarantee or insurances. Operators have the choice of different options. In terms of the ability to differentiate risks, Kammarkollegiet differentiates the amounts to be secured based on the turnover and activities of the particular operator. This seems to have the advantage that the duty to provide security can be linked to the economic activities of the operator. This, on the one hand, prevents amounts being demanded that are too low, and, on the other hand, prevents overly high amounts of security, which would impose an unnecessary burden on the operators. Failure provide to results in adequate information to Kammerkollegiet results in fines. Hence the Swedish system seems to be largely in line with this economic requirement. Furthermore there is no interrelation between a fund and insurance. One mechanism is to be chosen by one operator. In the Swedish model the Travel Guarantees Act simply forces every operator to lodge an individual security with an agency referred to as Kammarkollegiet. In terms of assuring that all operators participate in the system, monitoring and enforcement is crucial. The mandatory nature of the individual security does in principle exclude free riding and includes all operators within the system. Indeed, fines can and will be imposed for companies offering package deals without security. A breach of the obligation to

\footnotetext{
${ }^{57}$ Hof Den Haag 7 april 2009, LJN BK4880, TvC 2009, p. 265. Other "verzoeksschriftprocedure" can be found: http://www.consumentenautoriteit.nl/besluiten/verzoekschriftprocedures; http://www.consumentenautoriteit.nl/ nieuws/2010/consumentenautoriteit-gelijk-gesteld-rechtszaken-tegen-reisaanbieders.

58 See interview with the Consumer Authority, The Hague (23 March 2011).

${ }^{59}$ See interview with SGR, Rotterdam (17 August 2011).

${ }^{60}$ Regarding different enforcement traditions and mechanisms and their interplay, see Cafaggi and Micklitz (2009) and Weber (2012).
} 
provide for security mechanisms can also lead to imprisonment. Enforcement is carried out by the Swedish CO and to some extent by Kammarkollegiet itself. In exceptional cases, the police might be involved.

The system in the UK has a statutory basis in the package travel, package holiday, and package tour regulations. In theory, the Act allows for three different security mechanisms, i.e., bonds, insurance, or trusts, but the option trust is rejected by the ABTA, the professional association of travel agents. The bond that could be provided is linked to the annual turnover, but the amount of the bond is reduced if the institution providing the bond has either a reserve fund or an insurance cover. In principle, contributions can be risk dependent. Either the institution providing the bond or the insurance company can require risk-dependent premiums. It is, however, less clear how the obligation to provide financial security is controlled. For example, the relationship between the bond and the annual turnover of course requires a control of the adequacy of the posted bond. TSS are active in monitoring the fulfillment of these provisions, but their approach seems to differ with the different regulators. Criminal prosecutions carried out by these regulators are indeed possible. The coordination of the enforcement approach, however, seems to show some weaknesses. In theory, the OFT could discipline travel operators, but it has shown little engagement. In addition to public enforcement (via the TSS), The ABTA also imposes the obligation to comply with the guarantee provisions upon its members. Ninety per cent of package deals sold in the UK are offered by ABTA members, which leaves $10 \%$ not covered. For them, therefore, only public enforcement bodies can intervene, and public enforcement remains necessary in addition to private enforcement via ABTA. Exceptional cases of police involvement have been reported. There is an interrelation with a fund that steps in as soon as a flight is part of the deal. Notably, this fund currently runs with a huge deficit. As one might expect that in most package deals, there will be a flight element, the fund is crucial in the system. Notably, consumers finance this fund directly.

In The Netherlands, a fund was created before the obligation to provide for securities was set explicitly in the EU Package Travel Directive (in 1983), hence long before the entry into force of the Directive. It was organised by operators, but financed by consumers. Today's consumers profit from the contributions of past consumers. Traders continue to finance the administration of the fund. The SGR fund basically only applies to traders that are members of the travel operators' organization ANVR. For others (approximately $5 \%$ ) a duty to provide financial security still applies. These traders are scrutinised by the CA which can fine traders that do not meet this obligation. The travel association (ANVR) reports nonmembers who fail to provide the guarantee to the CA.

Participation in the SGR (which applies to the majority of travel operators in the Netherlands) is voluntary, but is mandatory for ANVR members. Their contribution depends on turnover, and the refusal to pay is sanctioned. Since this contribution only concerns the financing of the fund's administration, traders do not finance the whole system. Hence the SGR de facto functions as a fund and is operated by the operators themselves, which is desirable in terms of a heightened ability to differentiate risks. Then, again, their contribution only concerns the amounts necessary for administration of the fund, varying between $€ 270$ and $€ 1,356$ yearly. Other operators, however, are under an obligation to provide for an equivalent security mechanism. There is an interrelation with the catastrophes fund for a certain number of cases.

One important question involves the possible impact on the traders' incentives to internalise risks when consumers are involved in ensuring compensation in insolvency situations. This is an issue with the Dutch SGR - though in terms of current consumers profiting from the contributions of past consumers - and to some extent in the UK, namely with the ATT scheme. The mere fact that consumers contribute officially is as such not necessarily 
problematic. Even in countries where in principle the operator finances the compensation mechanism, the price of this compensation (for example an insurance premium) will undoubtedly be passed on to the consumer in the price of the package travel. This is obviously an application of the Coase Theorem (Coase 1960). In the event of passing on incentives can still work due to a price difference that operators have to make when offering deals. Consumers' direct involvement in financing security mechanisms has an inherent potential to lead to an element of under-deterrence if the traders do not face the full consequences of their risky behaviour. These risks seem to be given principally in The Netherlands. The differences made in contributions for the administration by different traders do not vary greatly; less risk differentiation takes place.

The most challenging part in designing security mechanisms is - not surprisingly - disciplining rogue traders, ensuring their compliance with the obligations. The question is how can the necessary mandatory nature of such a system - to guarantee the participation of rogue traders - be ensured. Therefore, the various possibilities in the countries to monitor the as such obligatory system shall be carefully considered. In The Netherlands, it is striking that the SGR fund basically only applies to traders that are members of the travel operators' organization ANVR. Traders that remain outside (approximately $5 \%$ ) are nevertheless required to provide financial securities. As stated, the CA has shown extensive involvement here. If one considers that traders who are interested in a long-term relationship with consumers and care about their reputation were to become members of the ANVR, the $5 \%$ of traders that remain outside might be particularly worrisome. In Sweden, the monitoring and enforcement of the general obligation to register with Kammarkollegiet is carried out by Kammarkollegiet itself, by the trade associations, and by the CO. Theoretically the police can be involved. In the UK, the trade association ABTA plays an important role in the monitoring and enforcement of the obligation to provide for securities. Notably, it has restricted the options to do so for its members to two out of three. It does not regard trusts to be a suitable mechanism; public regulators are then, involved. A weakness in the UK might be the lack of a coordinated national approach - in particular relating to traders who are not ABTA members. On the one hand the OFT does not become involved. On the other hand, the actual TSS involvement in the enforcement of package travel laws seems to differ. Traders could thus potentially forum shop and operate from regions where the TSS is passive and lenient.

\section{Concluding Remarks}

Following a short theoretical exercise, in this contribution we have addressed from an economic perspective the financial compensation mechanisms available in insolvency situations in three countries.

On the basis of a few core criteria regarding the reality in three countries, it is striking that they show certain similarities, but some remarkable differences as well. Risk differentiation, though differing slightly in form, is available in all three countries. The financing of the mechanisms starts from different premises. Consumers in The Netherlands, used to pay directly into a fund and are now rewarded for this by having a fund in place that can finance payments with capital gains on its assets. Traders contribute to the administration of the system only - thus, the differentiation only applies to this amount. This leads to overall fewer costs for traders. In the UK, financing is done by traders, with the exception of the ATT scheme for deals involving a flight element. Here, again, consumers are directly involved in the financing. In Sweden, administration of the system is carried out by a publicly financed government body which takes some burden of the costs from the traders. The reason that in 
particular countries a specific mechanism is developed often has to do with path dependency. In The Netherlands, for example, the SGR already existed and continued to be used. Interestingly, all systems also show some private/public partnerships in the sense that even where private mechanisms (like insurance) are dominant, public authorities still control whether the duty to provide financial security has been met, and they can and do initiate legal action in cases of noncompliance.

In terms of securing adherence to the mandatory legal provisions as to providing for financial guarantees for insolvency situations, it is noticeable that the Dutch CA and the Swedish CO have been more active than the British OFT. TSS engagement is higher or lower depending on each regulator - there are more than 200 TSS in the UK. There are, however, internal fining mechanism within ABTA, and there have been incidents of police involvement in the past relating to non-members.

A crucial issue is obviously that these financial security mechanisms have been created especially to control rogue traders that would indeed like to externalise insolvency risks to consumers. All systems try to some extent to deal with these. How is the mandatory nature of the mechanisms actually monitored? It is striking that there is obviously a common interest on the part of the public (represented by public enforcement) and the serious travel operators (often brought together in trade associations) to act precisely against these rogue traders. Hence, trade associations like the ABTA in the UK and the ANVR in The Netherlands also impose upon their members the obligation to provide financial security. However, it may in particular be the non-members of these associations who are the type of rogue traders for which public enforcement of the financial security obligation may be needed. Cases in Sweden and in The Netherlands show that public authorities (such as the Swedish CO or The Dutch CA) also go after these traders that seek to escape the obligations to provide financial security, but, as mentioned, this seems thus far to be less the case with the British OFT and TSS. The British approach is furthermore decentralized.

Of course, other mechanisms could also be designed to control rogue traders such as compulsory licenses for travel businesses. In this case, the competence and credit worthiness of a travel business could be determined before it commenced operations. However, these alternative tools may also involve substantial costs and disadvantages and are beyond the scope of this paper.

A particular problem arises in cases of transboundary consumer contracts. Indeed, most legal systems provide that operators have to comply with the financial security mechanisms applicable to the country from which they operate. Increasingly, especially as a result of internet trade, consumers also purchase travel package from operators situated abroad. This shows that, especially in the transboundary context, it is extremely important to guarantee compliance with the financial security system in every EU MS.

Acknowledgments We are grateful to the participants in the annual conference of the European Association for Law and Economics (Stockholm, 21 September 2012) for useful comments on an earlier version of this paper, as well as to two anonymous referees.

\section{References}

Becker, G. (1968). Crime and punishment: An economic approach. Journal of Political Economy, 76(2), $169-217$. Cafaggi, F., \& Micklitz, H.-W. (2009). New frontiers of consumer protection, the interplay between private and public enforcement. Intersentia: Antwerp.

Coase, R. H. (1960). The problem of social cost. Journal of Law and Economics, 3, 1-44.

Coghlin, T.G. (1994). Protection and indemnity clubs, Lloyd's Maritime and Commercial Law Quarterly, $403-416$ 
Faure, M. (2004). Alternative compensation mechanisms as remedy for uninsurability of liability. The Geneva Papers on Risk and Insurance, 29(3), 455-489.

Faure, M. G. (2006). Economic criteria for compulsory insurance. The Geneva Papers on Risk and Insurance, $31,149-168$.

Faure, M. G., \& Hartlief, T. (1986). Compensation funds versus liability and insurance for remedying environmental damage. Review of European Community and International Environmental Law (RECIEL), 5(4), 321-327.

Faure, M., \& Hartlief, T. (2003). Insurance and expanding systemic risks. Paris: OECD.

Faure, M., \& Heine, K. (2012). Insurance for financial crisis? New York University Journal of Law \& Business, 8(1), 117-150.

Faure, M., Ogus, A., \& Philipsen, N. (2008). Enforcement practices for breaches of consumer protection legislation. Loyola Consumer Law Review, 20, 361-401.

Grant, D., \& Mason, S. D. (2012). Holiday law: The law relating to travel and tourism (5th ed.). London: Sweet \& Maxwell.

Halbhuber, H., \& Hondius, E. (1996). Guarantee funds for the travel industry: Protection of the consumer against the insolvency of his organizer/retailer. Journal of Consumer Policy, 19(3), 305-337.

Hodges, C. (2009). Developing approaches to public and private enforcement in England and Wales. In F. Cafaggi \& H. W. Micklitz (Eds.), New frontiers of consumer protection-The interplay between private and public enforcement (pp. 151-169). Intersentia: Mortsel.

Jost, P. J. (1996). Limited liability and the requirement to purchase insurance. International Review of Law and Economics, 16, 259-276.

Loos, M. B. M., \& Van Boom, W. H. (2010). Handhaving Van Het Consumentenrecht-Preadviezen Nederlandse Vereniging Voor Burgerlijk Recht 2009. Deventer: Kluwer.

Micklitz, H.-W. (2004). The principles of European contract law and the protection of the weaker party. Journal of Consumer Policy, 27(3), 339-356.

Priest, G. (1987). The current insurance crisis and modern tort law. Yale Law Journal, 96, 1521-1590.

Schulte-Nölke, H. (2007). EC consumer law compendium-Comparative analysis. Bielefeld: University of Bielefeld.

Shavell, S. (1979). On moral hazard and insurance. Quarterly Journal of Economics, 93(4), 541-562.

Shavell, S. (1986). The judgment proof problem. International Review of Law and Economics, 6, 43-58.

Weber, F. (2012). Towards an optimal mix of public and private enforcement in consumer law: A comparative law and economics analysis of European consumer law enforcement (package travel vs. misleading advertising) (Dissertation, Erasmus School of Law). 